\title{
Correlation Between the Preparation Methods and the Structural Morphologies of Organometallic Halide Perovskite Thin Films
}

\author{
Mwende Mbilo*, Agumba Onyango John, Fanuel Keheze Mugwang’a \\ Department of Physics, School of Pure and Applied Sciences (SPAS), Pwani University, Kilifi, Kenya \\ Email address: \\ mwendebilo@gmail.com (M. Mbilo) \\ ${ }^{*}$ Corresponding author
}

To cite this article:

Mwende Mbilo, Agumba Onyango John, Fanuel Keheze Mugwang'a. Correlation Between the Preparation Methods and the Structural Morphologies of Organometallic Halide Perovskite Thin Films. Colloid and Surface Science. Vol. 4, No. 1, 2019, pp. 7-12. doi: $10.11648 /$ j.css.20190401.12

Received: March 15, 2019; Accepted: April 22, 2019; Published: May 11, 2019

\begin{abstract}
Organometallic halide perovskites are emerging as a promising class of materials for optoelectronic and electrical applications. The degree of molecular ordering that depends on nucleation and growth processes can tune their morphological structure which in turn affects the resultant optical, electronic and electrical properties. Studies have been carried out in this area of research, to some degree, but not conclusive. A systematic study on how the preparation method determines the various morphologies of the resultant perovskite thin films is thus necessary. This work presents a study that was carried out to assess the relationship between different deposition methods and the resulting morphologies of organometallic halide perovskite thin films. In this study, single step solution deposition method, two step solution deposition method and two step drop casting solution deposition methods were used to prepare the perovskite thin films. Concentration, annealing temperature, blade coating speed and dipping times were varied during perovskite deposition processes and the optical micrographs of the prepared films obtained using Zeiss Axio 100 optical microscope fitted with AxioCam 105 color camera. Significant difference in morphologies of the structures prepared using different deposition methods was observed. This observable difference in morphologies may be related to the molecular order of the film structures.
\end{abstract}

Keywords: Perovskite, Morphology, Solar Cells, Methyl Ammonium Lead Iodide $\left(\mathrm{CH}_{3} \mathrm{NH}_{3} \mathrm{PbI}_{3}\right)$, Thin Films

\section{Introduction}

Organometallic halide perovskite (OHP) solar cells have emerged as a promising technology for the next generation high efficiency solar cells [1]. Photovoltaic (PV) technology is compatible with low-cost, low-temperature processing and high power conversion efficiencies (PCE) [2]. Perovskites refers to a category of materials that can be represented by the building block of $\mathrm{ABH}_{3}$, where $\mathrm{A}$ is organic cation, $\mathrm{B}$ is metal cation and $\mathrm{H}$ is halide anion. Recent studies on oxide and halide based perovskites have indicated their potential applications in solar cells [3-5]. First reported in 2012 with a $10 \%$ efficiency [6], the lead halide perovskite-based absorbers have more than doubled in the recent time. In 2016, the highest reported efficiency was $22.1 \%$, comparable to common inorganic photovoltaic materials, such as copper, indium, gallium selenide and cadmium telluride [7]. The significant performance milestones of these metal halide perovskites have been reached due to the multiple fabrication methodologies developed for these devices [8]. Some of these fabrication methodologies include; dissolution-recrystallization process [9], template guide growth technology [10] and slip coating method [11]. Despite these recent developments, there is still uncovered ground in exploring the fabrication methodologies and their resultant morphology and performance properties. Chemical vapor deposition system was used by Son Tung Ha and co-workers to synthesis organic-inorganic lead halide perovskite nano platelets for high-performance perovskite solar cells and optoelectronic devices applications [12]. It was realized that there was a difference in platelets thickness for the different halide perovskites. However, this study did not look at the factors like annealing temperatures and annealing times which 
affects platelets morphology. A study was carried out on crystal structure formation of mixed halide perovskites using vapor based deposition methods [13]. The results showed change of color of the mixed halide perovskite films optical micrographs from yellow to dark as the reaction time was increased. This shows that increase of the perovskite reaction time leads to better conversion of the reactants to perovskite material. A study on Parameters influencing the deposition of methyl ammonium lead halide iodide in hole conductor free perovskite-based solar cells was conducted by Bat-El Cohen and co-workers [14]. Solution deposition methods were used to deposit perovskite thin films and thermally annealed films were compared with un-annealed films. The optical micrographs of the un-annealed films showed less coverage as compared to the annealed films. From this study, it was evident that thermal annealing affects the structural film morphology hence the overall performance of perovskite based solar cells. Sequential deposition is one of the main methods used for depositing perovskite films for various applications. It was optimized by Ummadisingu and co-workers [15] for the fabrication of solar cells. In this method, the formation of a $\mathrm{CH}_{3} \mathrm{NH}_{3} \mathrm{PbI}_{3}$ film was achieved through dipping $\mathrm{PbI}_{2}$ film in a solution of methylammonium iodide (MAI) in 2-propanol for up to 60 seconds, resulting in the formation of the perovskite. Large number of cluster like structures were formed whose sizes in increased with dipping times. This study did not consider using longer annealing times up to hours which could lead to growth of larger clusters. The fabrication of perovskites by evaporation methods has also been explored and successfully employed to prepare photovoltaic devices. One such study was carried out by Avila and co-workers [16] using vapor deposition method as a route to high performance solar cell production. Results reviewed increased film coverage as the concentration was increased which implies that concentration affects the film morphology. However this study did not look at the effects of annealing temperatures and time on the resulting morphologies of perovskite thin films.

From the mentioned studies, it is clear that the method used to prepare perovskite thin films has it's fingerprint on the morphology of the resultant thin film and thus further systematic studies to unveil this correlation are welcome. This study has thus focused on fabricating films of methyl ammonium lead iodide $\left(\mathrm{CH}_{3} \mathrm{NH}_{3} \mathrm{PbI}_{3}\right)$ model polymer using single step solution deposition method, two step solution deposition method and two step drop casting solution deposition method. By adjusting concentration, annealing temperatures, blade coating speed and dip coating times, different morphologies have been reported and the influence of these factors on the resulting morphologies of the films have been investigated.

\section{Material and Methods}

\subsection{Materials}

In this study, Lead iodide $\left(\mathrm{PbI}_{2}, 99.8 \%\right.$, Sigma Aldrich, $\mathrm{N}$, N-Dimethyl formamide (DMF, 99.8\%, Sigma Aldrich),
Isopropanol $\left(\mathrm{C}_{3} \mathrm{H}_{8} \mathrm{O}, 99.8 \%\right.$, Sigma Aldrich), Methyl ammonium iodide (MAI, 99.8\%, Solaronix) were used. All chemicals were used as received without further purification.

\subsection{Methods}

Dry ammonium salts were used to prepare perovskite samples. Three routes were used; single step solution deposition method, two step solution deposition method and two step drop casting solution deposition method. The reaction is described by the chemical formula;

$$
\mathrm{R}-\mathrm{NH}_{3} \mathrm{X}+\mathrm{MX}_{2}=\mathrm{R}-\mathrm{NH}_{3} \mathrm{MX}_{3}
$$

Where $\mathrm{R}$ is the methyl ammonium, $\mathrm{X}$ is iodide and $\mathrm{M}$ is lead.

\subsubsection{Single Step Solution Deposition Method}

$0.01 \mathrm{~g} / \mathrm{mL}, 0.012 \mathrm{~g} / \mathrm{mL}, 0.013 \mathrm{~g} / \mathrm{mL}, 0.014 \mathrm{~g} / \mathrm{mL}, 0.015 \mathrm{~g} / \mathrm{mL}$ and $0.02 \mathrm{~g} / \mathrm{mL}$ of $\mathrm{CH}_{3} \mathrm{NH}_{3} \mathrm{PbI}_{3}$ solutions were prepared by dissolving $\mathrm{PbI}_{2} / \mathrm{CH}_{3} \mathrm{NH}_{3} \mathrm{I}$ powders in $\mathrm{N}$, N-Dimethyl formamide (DMF) solution. The mixtures were kept at constant stirring at $70^{\circ} \mathrm{C}$ on a hot plate until they fully dissolved. The films were prepared by drop casting, slip coating, and blade coating the prepared solutions onto microscope glass slides cleaned with acetone and distilled water.

\section{i. Drop Casting Method}

$0.02 \mathrm{~g} / \mathrm{mL}$ of $\mathrm{CH}_{3} \mathrm{NH}_{3} \mathrm{PbI}_{3}$ solution prepared in single step solution deposition method was drop casted on microscope glass slides cleaned with acetone and distilled water. The solution was spread using a stirring rod to form thin films. The thin films were annealed in an oven at $80^{\circ} \mathrm{C}, 150^{\circ} \mathrm{C}$ and $170^{\circ} \mathrm{C}$ for 3 hours each and observed using Zeiss Axio 100 optical microscope fitted with AxioCam 105 color camera.

\section{ii. Slip Coating Method}

A drop of $0.01 \mathrm{~g} / \mathrm{mL} \mathrm{CH}_{3} \mathrm{NH}_{3} \mathrm{PbI}_{3}$ solution prepared by single step solution deposition method was dropped onto cleaned microscope slide and covered with a second microscope slide so that the excess solution squeezed out. The remaining solution formed a uniform liquid film between the glass slides. The excess $\mathrm{CH}_{3} \mathrm{NH}_{3} \mathrm{PbI}_{3}$ solution was removed from the sides by soaking with a tissue. Next, the bottom glass slide was held in place while gradually sliding the upper glass slide, exposing the thin liquid film to air. The sliding was performed manually. In order to prepare thicker films $0.012 \mathrm{~g} / \mathrm{mL}, 0.013 \mathrm{~g} / \mathrm{mL}, 0.014 \mathrm{~g} / \mathrm{mL}$ and $0.015 \mathrm{~g} / \mathrm{mL}$ of the solution were applied. The films were prepared at room temperature. Zeiss Axio 100 optical microscope fitted with AxioCam 105 color camera was used to observe the films.

\section{iii. Blade Coating Method}

$0.015 \mathrm{~g} / \mathrm{mL} \mathrm{CH}_{3} \mathrm{NH}_{3} \mathrm{PbI}_{3}$ solution prepared by single step solution deposition method was drop casted onto microscope glass slide cleaned with acetone and distilled water. A blade was dragged over the solution drop casted onto the glass slide at $1.33 \mathrm{cms}^{-1}, 0.86 \mathrm{cms}^{-1}, 0.67 \mathrm{cms}^{-1}, 0.57 \mathrm{cms}^{-1}$ and $0.5 \mathrm{cms}^{-1}$ blade coating speeds to remove excess of the solution and form thin films. The films were observed using Zeiss Axio 100 optical 
microscope fitted with AxioCam 105 color camera.

\subsubsection{Two-Step Solution Deposition Method}

$0.4 \mathrm{~g}$ of Lead (ii) iodide powder was dissolved in $20 \mathrm{~mL} \mathrm{~N}$, $\mathrm{N}$-Dimethyl formamide solvent to make a concentration of $0.02 \mathrm{~g} / \mathrm{mL}$. The mixture was kept at constant stirring at $70^{\circ} \mathrm{C}$ on a hot plate until it fully dissolved. $\mathrm{PbI}_{2}$ films were prepared by drop casting the prepared lead (ii) iodide solution on microscope glass slides cleaned with acetone and distilled and distilled water. The films were dried at $80^{\circ} \mathrm{C}$ in an oven for 20 minutes then cooled to room temperature. The films were dipped into a solution composed of $0.01 \mathrm{~g} / \mathrm{mL}$ methyl ammonium iodide in isopropanol solvent for 16 hours, 48 hours and 96 hours to form $\mathrm{CH}_{3} \mathrm{NH}_{3} \mathrm{PbI}_{3}$ films. The films were annealed at $80^{\circ} \mathrm{C}$ for 12 hours each. Zeiss Axio 100 optical microscope fitted with AxioCam 105 color camera was used to observe the films.

\subsubsection{Two Step Drop Casting Solution Deposition Method}

$0.005 \mathrm{~g} / \mathrm{mL}, 0.01 \mathrm{~g} / \mathrm{mL}$ and $0.015 \mathrm{~g} / \mathrm{mL}$ solutions of $\mathrm{PbI}_{2}$ were prepared by dissolving $\mathrm{PbI}_{2}$ powder into $\mathrm{N}, \mathrm{N}-\mathrm{DMF}$ solvent. The solutions were kept at a constant stirring until they fully dissolved. A solution of $\mathrm{CH}_{3} \mathrm{NH}_{3} \mathrm{I}$ was prepared by dissolving $\mathrm{CH}_{3} \mathrm{NH}_{3} \mathrm{I}$ into isopropanol solvent. A drop of $\mathrm{PbI}_{2}$ solutions was deposited onto microscope glass slides cleaned with acetone and distilled water and spread using a stirring rod to form thin films. A drop of $\mathrm{CH}_{3} \mathrm{NH}_{3} \mathrm{I}$ solution was then deposited onto the $\mathrm{PbI}_{2}$ films and spread using a stirring rod to form $\mathrm{CH}_{3} \mathrm{NH}_{3} \mathrm{PbI}_{3}$ films. The resulting films were annealed in an oven at $100^{\circ} \mathrm{C}$ for 10 minutes each and observed using Zeiss Axio 100 Optical Microscope fitted with AxioCam 105 color camera.

\section{Results and Discussion}
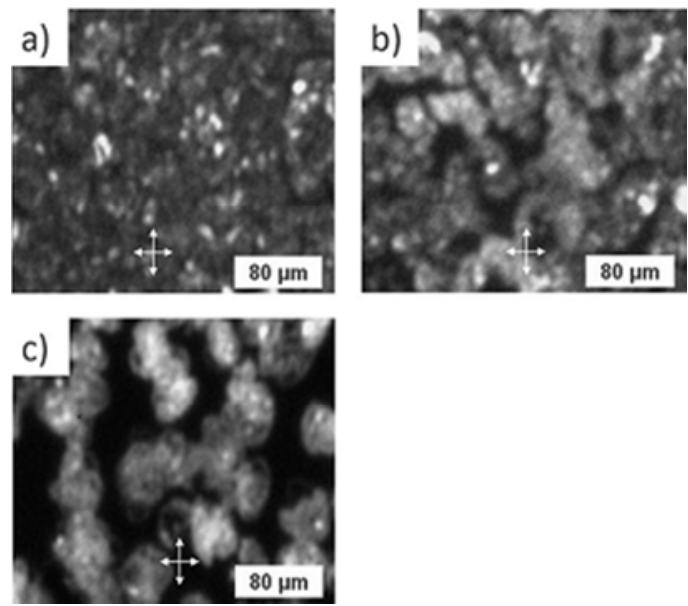

Figure 1. Birefringent images of $0.02 \mathrm{~g} / \mathrm{mL} \mathrm{CH} \mathrm{CH}_{3} \mathrm{NH}_{3} \mathrm{PbI}_{3}$ films prepared in single step solution deposition method by drop casting and annealed at, (a) $80^{\circ} \mathrm{C}$, (b) $150^{\circ} \mathrm{C}$ and (c) $170^{\circ} \mathrm{C}$ for 3 hours each showing structure number density and size dependence on temperature.

Annealing is an important step performed after deposition of perovskite films to tune the film crystallinity, to eliminate solvent residues, and to stabilize the perovskite structure. It was thus important to study how annealing temperature affects the perovskite conversion and the distribution and uniformity of perovskite crystalline structures. After deposition of $0.02 \mathrm{~g} / \mathrm{mL}$

$\mathrm{CH}_{3} \mathrm{NH}_{3} \mathrm{PbI}_{3}$ films and annealing at $80^{\circ} \mathrm{C}, 150^{\circ} \mathrm{C}$ and $170^{\circ} \mathrm{C}$ for 3 hours each, the films morphological changes of $\mathrm{CH}_{3} \mathrm{NH}_{3} \mathrm{PbI}_{3}$ were examined. The images shown in Figure 1 were obtained. Annealing resulted to different morphologies depending on the annealing temperatures. Figure 1 (c) shows that annealing at $170^{\circ} \mathrm{C}$, results in partial decomposition of perovskite since there is less surface coverage due to aggregation or sintering of perovskite crystals in severe thermal conditions.

By annealing the thin films at $80^{\circ} \mathrm{C}$, the clustered structures of the perovskite film were visible. The perovskites crystallite structures coverage was high but small in sizes. When annealed at $150^{\circ} \mathrm{C}$, the perovskite film formed larger and fewer crystalline domains with large spacing in between. As the annealing temperature was increased to $170^{\circ} \mathrm{C}$, the morphology of the perovskite film adopted more large individual aggregates with bigger spacing in between. It is thus evident that increasing the annealing temperature leads to the merging of nuclei into crystallite structures of material. We suggest that as annealing temperature was increased, the kinetic energy of the molecules increased. This increased the attachment probability as compared to detachment probability of the molecules. More molecules approached the growth front thus attaching themselves where there were maximum neighbors reducing the Gibbs free energy of the system. These results were in good agreement with the findings in the literature [17].

After deposition of different concentrations of $\mathrm{CH}_{3} \mathrm{NH}_{3} \mathrm{PbI}_{3}$ films using slip coating method at room temperature, the morphological changes of $\mathrm{CH}_{3} \mathrm{NH}_{3} \mathrm{PbI}_{3}$ films were examined. Figure 2 shows optical micrographs of the morphology changes of $\mathrm{CH}_{3} \mathrm{NH}_{3} \mathrm{PbI}_{3}$ films with concentration.
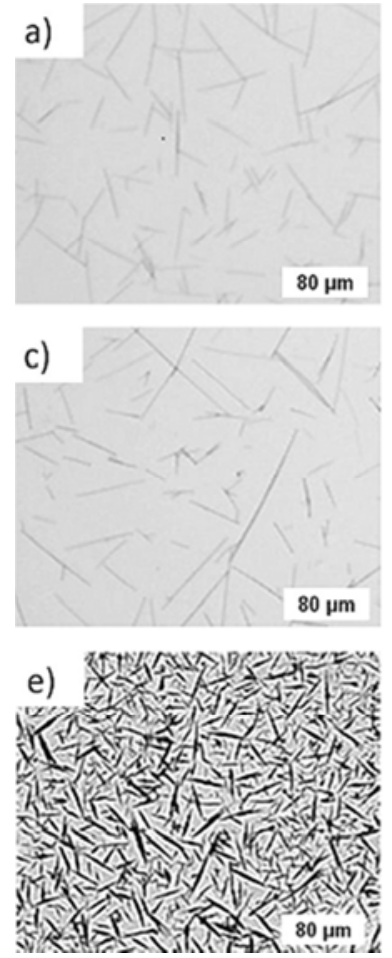

Figure 2. Optical micrographs (Bright field) of $\mathrm{CH}_{3} \mathrm{NH}_{3} \mathrm{PbI}_{3}$ films; (a) $0.01 \mathrm{~g} / \mathrm{mL}$, (b) $0.012 \mathrm{~g} / \mathrm{mL}$, (c) $0.013 \mathrm{~g} / \mathrm{mL}$, (d) $0.014 \mathrm{~g} / \mathrm{mL}$ and (e) $0.015 \mathrm{~g} / \mathrm{mL}$ prepared in single step solution deposition method by slip coating. 
As demonstrated in Figure 2, it was observed that the number density of the structures increased as the concentration was increased and the structure length decreased with an increase in concentration. Image $\mathrm{j}$ software

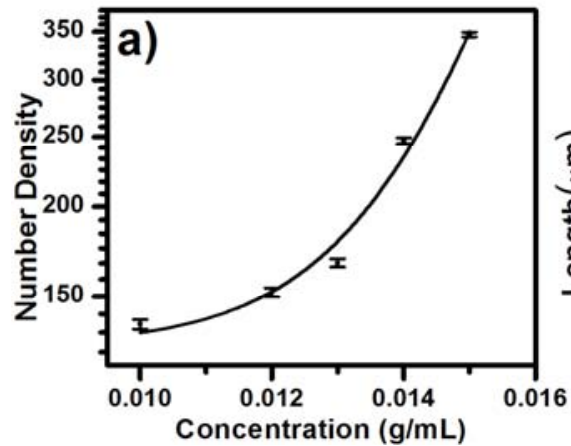

Figure 3. Graphs showing dependence of number density (a) and length of structure (b) on concentration.

From Figure 3 (a), the number density increased as the concentration of methyl ammonium lead iodide films was increased. This is because increase in concentration led to increased number of molecules, consequently many nucleation centers formed increasing the crystal number density. From the graph (Figure $3(\mathrm{~b})$ ), the length of structure decreased as the concentration was increased. This showed a slowed growth rate which may be associated with the reduction in thermodynamic driving force for growth with increased concentration as more molecules attach into the crystal. These results are in good agreement with the work of Horváth and coworkers which reported that growth rate could be affected by the driving force for growth with change in concentration [18].
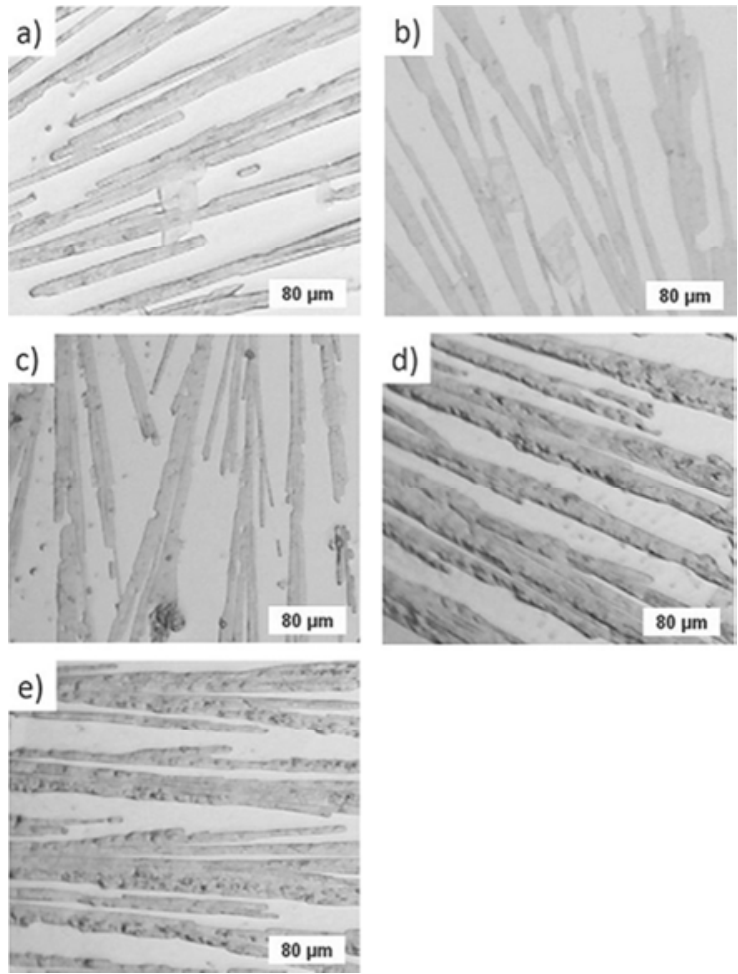

Figure 4. Optical micrographs (Bright field) of $\mathrm{CH}_{3} \mathrm{NH}_{3} \mathrm{PbI}_{3}$ films; (a) $1.33 \mathrm{cms}^{-1}$, (b) $0.86 \mathrm{cms}^{-1}$, (c) $0.67 \mathrm{cms}^{-1}$, (d) $0.57 \mathrm{cms}^{-1}$ and (e) $0.5 \mathrm{cms}^{-1}$ blade coating speeds prepared in single step solution deposition method by blade coating. was used to estimate the number of structures and average structure length and semi log graphs of dependence of number density and structure length on concentration were plotted as shown in Figure 3.

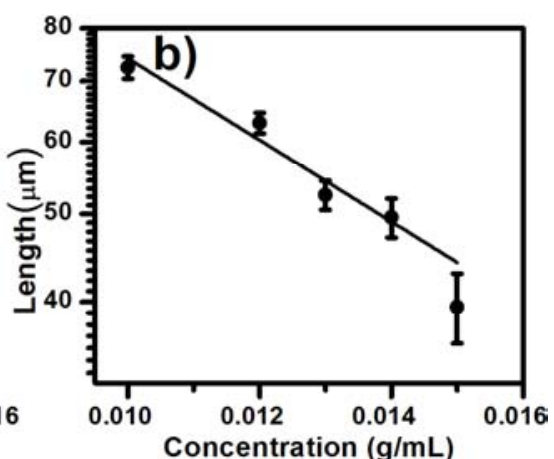

After deposition of $\mathrm{CH}_{3} \mathrm{NH}_{3} \mathrm{PbI}_{3}$ films using blade coating method at different blade coating speeds, the morphological changes of $\mathrm{CH}_{3} \mathrm{NH}_{3} \mathrm{PbI}_{3}$ films were examined. Figure 4 shows optical micrographs of the morphology changes of $\mathrm{CH}_{3} \mathrm{NH}_{3} \mathrm{PbI}_{3}$ films with the blade coating speeds.

As shown in Figure 4, it was observed that rod like structures of $\mathrm{CH}_{3} \mathrm{NH}_{3} \mathrm{PbI}_{3}$ films aligned along blade moving direction were formed. The formation of these structures could be explained by the fact that when a blade was put at the front of the $\mathrm{CH}_{3} \mathrm{NH}_{3} \mathrm{PbI}_{3}$ solution, a contact line was formed arresting the solution front due to surface roughness of the glass substrate. Upon evaporation, $\mathrm{CH}_{3} \mathrm{NH}_{3} \mathrm{PbI}_{3}$ molecules precipitated out to form nuclei and aggregated along the contact line. The movement of the contact line was controlled by the blade shear drag force. With the blade gradually receding, additional $\mathrm{CH}_{3} \mathrm{NH}_{3} \mathrm{PbI}_{3}$ molecules continuously flew towards the growing sites (nuclei) where they self-assembled and grew preferentially to form aligned rod like structures under the strong intermolecular interactions between adjacent $\mathrm{CH}_{3} \mathrm{NH}_{3} \mathrm{PbI}_{3}$ molecules. Further, it was observed from Figure 4 that the rod like structures thickened when the blade coating speeds decreased. This shear thickening could be explained as the behavior caused by the shear-induced crystallization of the $\mathrm{CH}_{3} \mathrm{NH}_{3} \mathrm{PbI}_{3}$ molecules and the reduced resistance when layers of ordered rods glide over one another. These findings agree with the existing literature [19].

After preparation of $\mathrm{CH}_{3} \mathrm{NH}_{3} \mathrm{PbI}_{3}$ films in two step solution deposition method for 16 hours, 48 hours and 96 hours of dipping times, the morphological changes of $\mathrm{CH}_{3} \mathrm{NH}_{3} \mathrm{PbI}_{3}$ films were examined. The optical micrographs shown in Figure 5 were obtained.

Large numbers of non-uniformly distributed structures on the film surface were formed within first 16 hours of dipping (Figure 5). The structures self-assembled into larger and well-ordered honey comb- like structures after 48 hours and 96 hours of dipping which is consistent with the crystal growth of $\mathrm{CH}_{3} \mathrm{NH}_{3} \mathrm{PbI}_{3}$ reported elsewhere [20]. As observed above, the morphology of $\mathrm{CH}_{3} \mathrm{NH}_{3} \mathrm{PbI}_{3}$ structures gradually changed with change in dipping time. This 
morphological change can be explained by the dissolution-recrystallization mechanism which takes place during $\mathrm{CH}_{3} \mathrm{NH}_{3} \mathrm{PbI}_{3}$ crystal ripening [20]. As dissolution-recrystallization process begins, small grains preferably dissolve into the bulk solution because of their high chemical potential; however, as dipping time increases recrystallization process happens on large grains to minimize Gibbs free energy. Consequently, the favorably oriented growth results in well-ordered structures with honey- comb like shape. This transition was consistent with Ostwald's 'Rule of Stages' [21] in which a metastable precursor is first formed and then transformed into the more stable product.
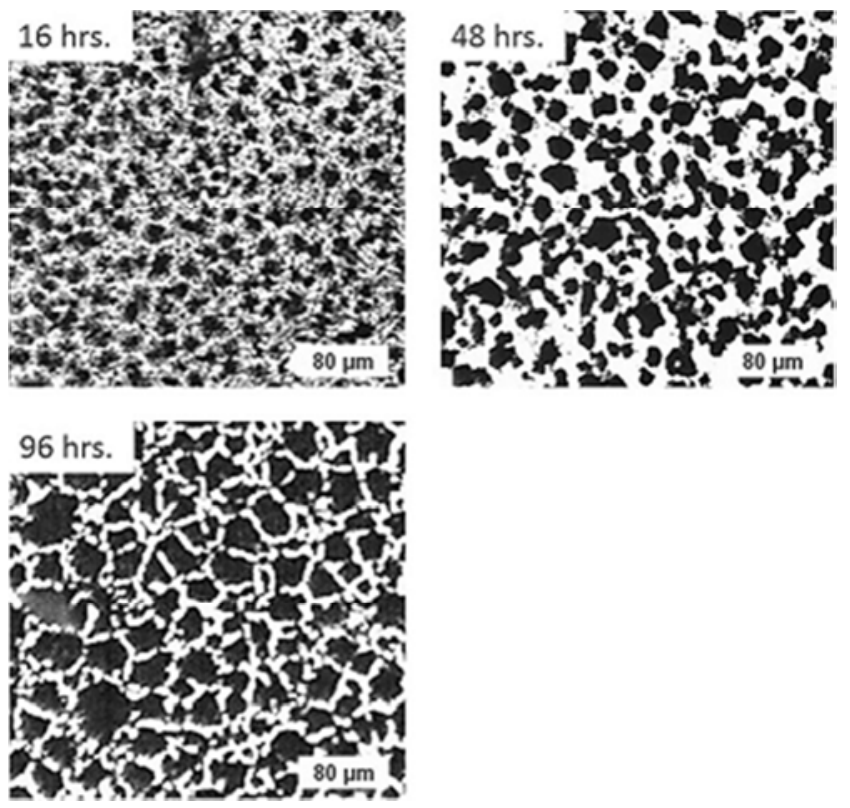

Figure 5. Optical micrographs (Bright field) of $\mathrm{CH}_{3} \mathrm{NH}_{3} \mathrm{PbI}_{3}$ films prepared by two step solution deposition method; (dipping $\mathrm{PbI}_{2}$ films in $\mathrm{CH}_{3} \mathrm{NH}_{3} \mathrm{I}$ Solution for 16 hours, 48 hours and 96 hours) showing increase sizes with increase in dip coating times.

Generally speaking, increasing the dipping time of the $\mathrm{Pbl}_{2}$ layer in the MAI solution provides longer time for conversion of precursors to perovskite crystals. However, excessive exposure times may cause dissolution of the perovskite layer, leading to film deterioration or a decrease in coverage [22].

After deposition of $0.005 \mathrm{~g} / \mathrm{mL}, 0.01 \mathrm{~g} / \mathrm{mL}$ and $0.015 \mathrm{~g} / \mathrm{mL}$ $\mathrm{CH}_{3} \mathrm{NH}_{3} \mathrm{PbI}_{3}$ films by two step drop casting solution deposition method, the morphological changes of $\mathrm{CH}_{3} \mathrm{NH}_{3} \mathrm{PbI}_{3}$ films were examined. The bright field optical micrographs of $\mathrm{CH}_{3} \mathrm{NH}_{3} \mathrm{PbI}_{3}$ films were observed as shown in Figure 6.

From Figure 6, it was observed that the number density increased as the concentration of methyl ammonium lead iodide films was increased. This is because increase in ratio led to increased number of molecules, consequently many nucleation centers formed increasing the crystal number density.
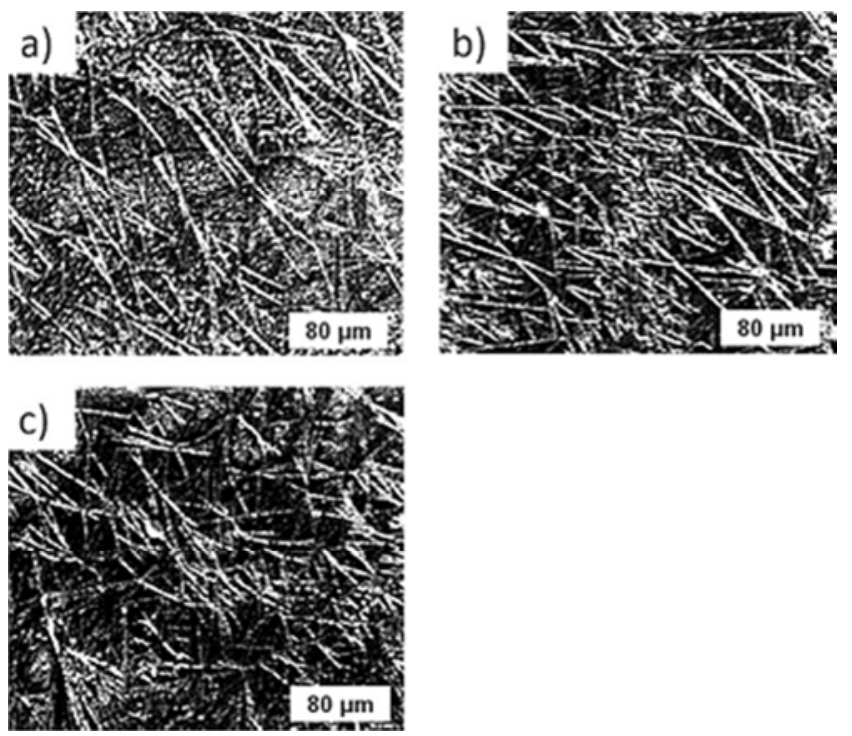

Figure 6. Optical micrographs (Bright field) of (a) $0.005 \mathrm{~g} / \mathrm{mL}$, (b) $0.01 \mathrm{~g} / \mathrm{mL}$ and (c) $0.015 \mathrm{~g} / \mathrm{mL} \mathrm{CH} \mathrm{CH}_{3} \mathrm{NH}_{3} \mathrm{PbI}_{3}$ films prepared by two step drop casting solution deposition method; (drop casting $\mathrm{CH}_{3} \mathrm{NH}_{3} \mathrm{I}-\mathrm{IPA}$ solution onto drop casted $\mathrm{PbI}_{2}$ film) showing increase in number of structures with increase in concentration.

\section{Conclusion}

Monitoring of deposition techniques for solution processable perovskite films is a necessary process in the path towards their high performance. From this study, the films prepared using different deposition methods showed significant differences in morphology. Single step solution deposition method showed cluster-shaped, rod-shaped and needle-shaped structures from different film preparation methods depending on the concentration, annealing temperatures and blade coating speeds. The structures formed by the two step solution deposition method showed honey comp - shaped structures while those formed by two step drop casting solution deposition method showed rod-shaped structures. The morphology of these structures changed as the concentration, annealing temperatures, blade coating speed and dip coating times were varied. From this study, it can be concluded that concentration, annealing temperatures and dip coating times can be used to tune the morphologies of methyl ammonium lead iodide thin films. These results may open up routes towards high photovoltaic performance.

\section{Acknowledgements}

The authors are very grateful to the department of physics, Pwani University for availing the instruments and facilities used in this study.

\section{References}

[1] A. T. Barrows, A. J. Pearson, C. K. Kwak, A. D. F. Dunbar, A. R. Buckley, D. G. Lidzey, Efficient planar heterojunction mixed-halide perovskite solar cells deposited via spray-deposition, Energy Environ. Sci. 7 (2014) 2944-2950. 
[2] M. Liu, M. B. Johnston, H. J. Snaith, Efficient planar heterojunction perovskite solar cells by vapour deposition, Nature 501 (2013) 395-398.

[3] N. Park, Perovskite solar cells: an emerging photovoltaic technology, Biochem. Pharmacol. 18 (2015) 65-72.

[4] Y. Rong, L. Liu, A. Mei, X. Li, H. Han, Beyond Efficiency: the Challenge of Stability in Mesoscopic Perovskite Solar Cells, Adv. Energy Mater. 5 (2015) 1501066.

[5] S. Kazim, M. K. Nazeeruddin, M. Grätzel, S. Ahmad, Perovskite as light harvester: A game changer in photovoltaics, Angew. Chemie - Int. Ed. 53 (2014) 2812-2824.

[6] J. L. Barnett, V. L. Cherrette, C. J. Hutcherson, M. C. So, Effects of Solution-Based Fabrication Conditions on Morphology of Lead Halide Perovskite Thin Film Solar Cells, Adv. Mater. Sci. Eng. 2016 (2016) 1-2.

[7] J. M. Frost, K. T. Butler, C. H. Hendon, Atomistic Origins of High- Performance in Hybrid Halide Perovskite Solar Cells, Nano Lett. 14 (2014) 2584-2590.

[8] H. J. Snaith, Perovskites: The Emergence of a New Era for Low-Cost, High-Efficiency Solar Cells, J. Phys. Chem. Lett. 4 (2013) 3623-3630.

[9] H. Yu, F. Wang, F. Xie, The role of chlorine in the formation process of methyl ammonium lead triodide perovskite, Adv. Funct. Mater. 24 (2014) 7102-7108.

[10] W.-J. Yin, T. Shi, Y. Yan, Unique Properties of Halide Perovskites as Possible Origins of the Superior Solar Cell Performance, Adv. Mater. 26 (2014) 4653-4658.

[11] F. Hao, C. C. Stoumpos, R. P. H. Chang, M. G. Kanatzidis, Anomalous band gap behavior in mixed $\mathrm{Sn}$ and $\mathrm{Pb}$ perovskites enables broadening of absorption spectrum in solar cells, J. Am. Chem. Soc. 136 (2014) 8094-8099.

[12] S. T. Ha, X. Liu, Q. Zhang, D. Giovanni, T. C. Sum, Q. Xiong, Synthesis of Organic-Inorganic Lead Halide Perovskite Nanoplatelets: Towards High-Performance Perovskite Solar Cells and Optoelectronic Devices, Adv. Opt. Mater. 2 (2014) 838-844.
[13] S. Luo, W. A. Daoud, Crystal Structure Formation of $\mathrm{CH}_{3} \mathrm{NH}_{3} \mathrm{PbI}_{3}-\mathrm{xClx}$ Perovskite, J. Mater. 123 (2016) 2-4.

[14] B. Cohen, S. Gamliel, L. Etgar, Parameters influencing the deposition of methylammonium lead halide iodide in hole conductor free perovskite-based solar cells, APL Mater. 081502 (2014) 1-9.

[15] A. Ummandisingu, M. Gratzel, Revealing the detailed path of Sequential deposition for metal halide perovskite formation, Sci Adv. 4 (2018) 1-6.

[16] J. Avila, C. Momblona, P. P. Boix, M. Sessolo, H. J. Bolink, Vapor-Deposited perovskites: The route to high performance solar cell production, CellPress. 1 (2017) 431-442.

[17] Y. Tidhar, E. Edri, H. Weissman, D. Zohar, Crystallization of methyl ammonium lead halide perovskites: Implications for photovoltaic applications, J. Am. Chem. Soc. 136 (2014) 13249-13256.

[18] E. Horváth, M. Spina, Zs. Szekrényes, Nanowires of lead-methylamine iodide $\left(\mathrm{CH}_{3} \mathrm{NH}_{3} \mathrm{PbI}_{3}\right)$ prepared by low temperature solution-mediated crystallization, Nano Lett. 14 (2014) 1-11.

[19] W. Deng, X. Zhang, L. Huang, Aligned Single-Crystalline Perovskite Microwire Arrays for High-Performance Flexible Image Sensors with Long-Term Stability, Adv. Mater. 28 (2016) 2201-2208.

[20] T. Y. Hsieh, C. K. Huang, T. Sen Su, C. Y. Hong, Crystal Growth and Dissolution of Methylammonium Lead Iodide Perovskite in Sequential Deposition: Correlation between Morphology Evolution and Photovoltaic Performance, ACS Appl. Mater. Interfaces. 9 (2017) 8623-8633.

[21] Y. Chen, M. He, J. Peng, Structure and growth control of organic-inorganic halide perovskites for optoelectronics: From polycrystalline films to single crystals, Adv. Sci. 3 (2016) 7-8.

[22] M. R. Ahmadian-Yazdi, F. Zabihi, M. Habibi, Effects of Process Parameters on the Characteristics of Mixed-Halide Perovskite Solar Cells Fabricated by One-Step and Two-Step Sequential Coating, Nanoscale Res. Lett. 11 (2016) 6-7. 